\title{
Now Disease Reports \\ Hyparrhenia grass white leaf disease, associated with a 16SrXI phytoplasma, newly reported in Kenya
}

\author{
E. Obura ${ }^{1}$, D. Masiga ${ }^{1}$, C.A.O. Midega ${ }^{1}$, M. Otim ${ }^{2}$, F. Wachira ${ }^{3}$, J. Pickett ${ }^{4}$ and Z.R. Khan ${ }^{1}$ \\ ${ }^{1}$ International Centre of Insect Physiology and Ecology, 00100-30772, Nairobi, Kenya; ${ }^{2}$ National Crops Resources \\ Research Institute, 7084, Kampala, Uganda; ${ }^{3}$ Egerton University, 20113-536, Egerton, Kenya; ${ }^{4}$ Rothamsted Research, \\ Harpenden, Hertfordshire AL5 2JQ, UK
}

*E-mail: eobura@icipe.org

Received: 11 Aug 2011. Published: 02 Nov 2011.

Hyparrhenia rufa is a thatching grass commonly found throughout the tropics where it also serves as valuable cattle fodder and border grass to prevent soil erosion (Skerman \& Riveros, 1990). In June 2010, we observed some $H$. rufa plantsin the wild grasslands at several locations of Lambwe Valley in western Kenya that were stunted and appeared bushy, with small white leaves (Fig. 1), symptoms resembling those associated with Napier stunt disease in Kenya (Jones et al., 2004). Unlike the adjacent healthy plants that were flowering, plants with these symptoms did not produce flowers. Phytoplasma aetiology being suspected, leaf samples were taken from each of 11 symptom-bearing and symptomless plants, stored in liquid nitrogen and taken to the laboratory for phytoplasma analysis. DNA was extracted from $1 \mathrm{~g}$ of leaf tissue using the hot CTAB method of Doyle \& Doyle (1990). The extracted DNA was used as the template in a phytoplasma nested PCR assay with $16 \mathrm{~S}$ ribosomal DNA (16S rDNA) universal primers P1/P6 (Deng \& Hiruki, 1991) and R16F2n/R16R2 (Gundersen \& Lee, 1996). Phytoplasma infection was confirmed by amplification of $1200 \mathrm{bp}$ rDNA fragments from all the samples showing symptoms (11/11, Fig. 2), while no amplification was recorded in the symptomless samples (0/11). The 1200 bp rDNA fragments were gel purified (GeneJETTM Gel Extraction Kit, Fermentas), and sequenced directly. The consensus partial nucleotide sequence was submitted to GenBank (Accession No. JN112372), and used to query the non-redundant database using BLAST (Altschul et al., 1990). Sequence analysis revealed highest $16 \mathrm{~S}$ rDNA sequence identity (99\%) of the Hyparrhenia grass white leaf (HGWL) phytoplasma with that of the Napier grass stunt phytoplasma (GenBank Accession No. AY377876), confirming the HGWL phytoplasma as a member of the $16 \mathrm{SrXI}$ phytoplasma group ('Candidatus Phytoplasma oryzae').

To our knowledge, this is the first record of the group 16SrXI, ' $\mathrm{Ca}$. Phytoplasma oryzae' associated with the white leaf disease of $H$. $r u f a$, and the first record of the thatching grass as a host for a phytoplasma. This report also shows that $H$. rufa may be an alternative host plant for the
Napier grass stunt phytoplasma and might play a role in the epidemiology of Napier grass stunt disease in East Africa. As the disease spreads, it will affect the continued use of $H$. rufa as cattle fodder and thatching grass. The disease will negatively impact soil conservation efforts in parts of East Africa where $H$. rufa is the main border grass.

\section{Acknowledgements}

The work was funded by ICGEB-TWAS-UNESCO/IBSP, the Kenya National Council for Science and Technology, McKnight Foundation and the German Academic Exchange Programme.

\section{References}

Altschul SF, Gish W, Miller W, Myers EW, Lipman DJ, 1990. Basic local alignment search tool. Journal of Molecular Biology 215, 403-410.

Deng S, Hiruki C, 1991. Amplification of 16 S rRNA genes from culturable and non-culturable mollicutes. Journal of Microbiological Methods 14, 53-61. [doi:10.1016/0167-7012(91)90007-D]

Doyle JJ, Doyle JL, 1990. Isolation of plant DNA from fresh tissue. Focus 12, 13-15.

Gundersen DE, Lee IM, 1996. Ultrasensitive detection of phytoplasmas by nested-PCR assays using two universal primer sets. Phytopathologia Mediterranea 35, 144-151.

Jones P, Devonshire BJ, Holman TJ, Ajanga S, 2004. Napier grass stunt: a new disease associated with a $16 \mathrm{SrXI}$ group phytoplasma in Kenya. Plant Pathology 53, 519. [doi:10.1111/j.1365-3059.2004.01038.x]

Skerman PJ, Riveros F, 1990. Tropical Grasses. (FAO Plant Production and Protection Series (FAO), No. 23).Rome, Italy: FAO Publications [http://www.fao.org/ag/AGP/AGPC/doc/Gbase/Data/Pf000259.htm].

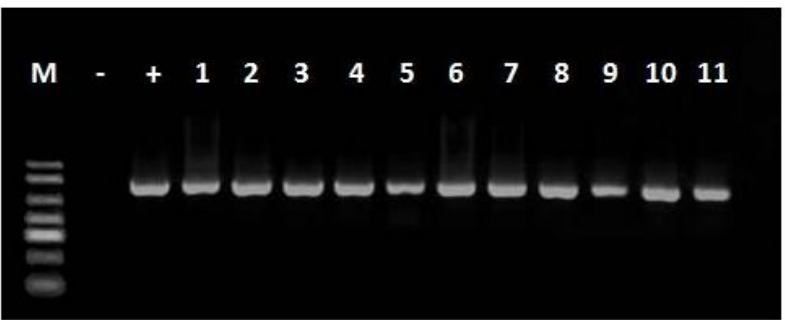

Figure 2

Figure 1

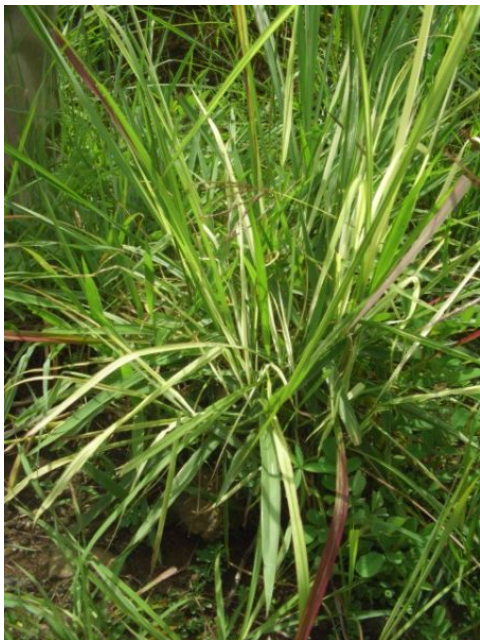

To cite this report: Obura E, Masiga D, Midega CAO, Otim M, Wachira F, Pickett J, Khan ZR, 2011. Hyparrhenia grass white leaf disease, associated with a 16SrXI phytoplasma, newly reported in Kenya. New Disease Reports 24, 17. [doi:10.5197/j.2044-0588.2011.024.017] (c) 2011 The Authors This report was published on-line at www.ndrs.org.uk where high quality versions of the figures can be found. 